\title{
Growth and productivity of tomato under use of biostimulant and ages of seedling transplantation
}

Talles Victor Silva, Hyrandir Cabral Melo, Luiz Fernandes Cardoso Campos, Monita Fiori de Abreu Tarazi, Luis Carlos Cunha Junior, Abadia dos Reis Nascimento

Universidade Federal de Goiás - UFG, GO. E-mail: luizfernandes.agronomo@gmail.com

\begin{abstract}
The age of the seedlings in the transplant, as well as the use of biostimulants in their production, are factors that can influence the good quality of the seedlings, which is fundamental for the good development of the plant, and can affect the yield of the tomato crop. The objective of this study was to evaluate plant development and fruit yield according to the age of tomato seedlings, during transplantation, whether or not treated with the Stimulate ${ }^{\circledR}$ biostimulant. The hybrid $\mathrm{H} 9553$ was used, and the experiment was conducted in a randomized block design, with four replications, and ten plants were evaluated, per plot. The factorial scheme $2 \times 6$ was adopted, where 2 corresponds to the use or not of Stimulate ${ }^{\circledR}$, and 6 corresponds to the age of the seedlings, in the transplant. Before transplantation, the height of the seedling, length of the root, stem diameter, number of leaves, fresh and dry mass of the aerial part and the root were evaluated at 20,30, 40, 50, 60 and 70 days after sowing. At 78 days after transplantation, the length of the main stem, stem diameter, number of fruits per plant, total fruit mass per plant and average fruit mass were evaluated. Seedlings with seventy days show superior results for the morphological characteristics, however, this does not interfere in the yield of the culture. The use of Stimulate ${ }^{\circledR}$, alone or in interaction with the age of the seedlings, does not influence plant growth or fruit yield.
\end{abstract}

Key words: H9553 cultivar; hormones; yield; Solanum lycopersicum L.; Stimulate .

Crescimento e produtividade de tomate sob uso de biostimulante e idades de transplante das mudas

\section{Resumo}

A idade das mudas no transplante, bem como o uso de bioestimulantes em sua produção, são fatores que podem influenciar na boa qualidade das mudas, fundamental para o bom desenvolvimento da planta, podendo afetar o rendimento da cultura do tomate. Objetivou-se com este estudo avaliar desenvolvimento da planta e o rendimento de frutos em função da idade das mudas de tomateiro, no transplante, tratadas ou não com o bioestimulante Stimulate ${ }^{\circledR}$. Foi utilizado o híbrido H9553, e o experimento foi conduzido em delineamento de blocos casualizados, com quatro repetições, e avaliadas dez plantas, por parcela. Foi adotado o esquema fatorial $2 \times 6$, onde 2 corresponde ao uso ou não de Stimulate ${ }^{\circledR}$, e 6 corresponde à idade das mudas, no transplante. Antes do transplante avaliou-se a altura da muda, comprimento da raiz, diâmetro do caule, número de folhas, massa fresca e seca da parte aérea e da raiz, aos 20, 30, 40, 50, 60 e 70 dias após a semeadura. Aos 78 dias após o transplante avaliou-se o comprimento da haste principal, diâmetro do caule, número de frutos por planta, massa total dos frutos por planta e massa média dos frutos. Mudas com setenta dias apresentam resultados superiores para as caraterísticas morfológicas, porém, isso não interfere no rendimento da cultura. $O$ uso do Stimulate ${ }^{\circledR}$, isoladamente ou em interação com a idade das mudas, não influencia no crescimento das plantas ou no rendimento de frutos.

Palavras-chave: cultivar H9553; hormônios; rendimento; Solanum lycopersicum L.; Stimulate ${ }^{\circledR}$. 


\section{Introduction}

The tomato (Solanum lycopersicum L.), whether in natura (fresh market tomatoes) or processed (industrial tomatoes), is one of the most consumed vegetables worldwide and also one of the most important for job and income creation, justifying its expressive participation in agribusiness (COSTA; HEUVELINK, 2018).

In the cultivation of most vegetables, including tomatoes, the practice of seedlings transplant is very common, especially for species with small seeds and also those of high cost (MAGRO et al., 2011). The seedlings age, at the time of transplantation, can be an important factor capable of affecting the plant quality and yield crop. When seedlings are kept for longer periods until transplantation, they tend to have greater tolerance for handling, especially because a well-structured root system more integrated with the clod (SEABRA JÚNIOR et al., 2004), but the seedlings can have nutritional deficiencies, in addition to the root system folding (BOVl; MINAMI, 1999). When the seedlings are very small, it maximizes the damage of the transplant handling causing loss of success of the establishment in the field (AGEHARA; LESKOVAR, 2015). The seedlings age at transplanting is also considered on the phytosanitary control of the plants because management conditions can favor bacterial infection (THOMAS; UPRETI, 2014).

In order to obtain high quality seedlings, in addition to the age aspect, biostimulants have been used in vegetable seeds and seedlings by nurseries (PALANGANA et al., 2012; IZIDÓRIO et al., 2015; MASONDO et al., 2019; NEMAHUNGUNI et al., 2020), however, the results obtained are very diverse. It is known that the effects of biostimulants on seedlings can vary according to the genotype (VENDRUSCOLO et al., 2016a). In tomato, the use of the Stimulate biostimulant in the germination and initial seedlings growth of the cultivar Santa Clara improved the germination percentage, germination speed and root production (VENDRUSCOLO et al., 2016a) and when used in cultivar Gaucho promoted an increase in plant height, leaves number, leaf width, leaf length and shoot dry mass (VENDRUSCOLO et al., 2016b). When used in seedlings of the Pizzadoro hybrid tomato there was no increase in dry mass of shoot, although it promoted increase of the leaves number, stem diameter and plant height (SIRTOLI et al., 2008). The use of this biostimulant in adult tomatoes plant of the cultivar Carmen also promoted an increase in fruits number (TAVARES et al., 2015).

It should be noted that tomato plants development and yield can be influenced by seedlings age when transplanted (JANKAUSKIENO' et al., 2013; JAISWAL et al., 2017) but also could not be influenced (LESKOVAR et al., 1991). The genotype and conditions of the environment are conditioning factors for these effects (SARKER et al., 2017). In this case, new studies are always necessary for the different genotypes and the environmental cultivation conditions. When adding the seedlings age factor to the biostimulant use, whose responsiveness of the plant also depends on the genotype (SIRTOLI et al., 2008), on tomato plant development and yield, two factors of high interest of farmers are added to rationalize time and cost in production.

The objective of this study was to evaluate plant development and fruit yield according to the age of tomato seedlings, during transplantation, whether or not treated with the Stimulate ${ }^{\circledR}$ biostimulant.

\section{Material and Methods}

The experiment was carried out in the experimental area of the Horticulture Sector of the School of Agronomy of the Universidade Federal de Goiás, Brazil, located at 16035'S latitude, 4921' $\mathrm{W}$ longitude and $727 \mathrm{~m}$ altitude. The soil in the area was classified as a dystrophic Red Latosol, with a clay texture. The local climate is classified as Rainy Tropical (Aw) in the International Köppen System. The experiment was conducted from March to July 2016, with a precipitation peak of $32 \mathrm{~mm}$ in March, less than $5 \mathrm{~mm}$ in May and the others months with zero precipitation. The minimum temperature ranged between 23 and $9{ }^{\circ} \mathrm{C}$ and the maximum temperature ranged between 23 and $35^{\circ} \mathrm{C}$.

The genetic material used was the tomato hybrid H9553, Heinz Seeds Company, which is one of the most cultivated in Brazil for industrial purpose. Seedlings were produced in a nursery. Six sowings were carried out distanced ten days one to other in order to unify the transplanting day. Seedlings were produced in polypropylene trays of 450 cells, filled with coconut fiber and covered with vermiculite (JORGE et al., 2016). Two trays were sown for each seedlings age, so that one was treated with biostimulant and the other not. 
According to the soil analysis (Table 1), it was corrected with the application of caucareous in order to reach saturation base of 70\% (SILVA et al., 2012). Planting fertilization with the formulation 4-30-10 (N-P-K), $1000 \mathrm{~kg} \mathrm{ha}{ }^{-1}$, followed the technical recommendations for the crop, as a result of the soil analysis (COMISSÃO DE FERTILIDADE DE SOLOS DE GOIÁS, 1988). Fertilizer was distributed and incorporated into the furrows one day before transplanting, followed by irrigation until soil saturation. The soil was previously prepared with plowing and two harrows.

Table 1. Soil analysis of the experimental area.

\begin{tabular}{|c|c|c|c|c|c|c|c|c|c|}
\hline Clay & Silt & Sand & MO & $\begin{array}{c}\mathrm{pH} \\
\left(\mathrm{CaCl}_{2}\right)\end{array}$ & $\begin{array}{c}\mathrm{P} \\
\mathrm{mg} / \mathrm{dm}^{3}\end{array}$ & $\begin{array}{c}\mathrm{K} \\
\mathrm{mg} / \mathrm{dm}^{3}\end{array}$ & \multicolumn{3}{|c|}{---------- cmolc/dm³ } \\
\hline 37.3 & 13.3 & 49.3 & 2.0 & 6.4 & 32.6 & 100.0 & 3.7 & 1.4 & 2.5 \\
\hline $\mathrm{Al}$ & CTC & M & V & $\mathrm{Ca} / \mathrm{Mg}$ & $\mathrm{Mg} / \mathrm{K}$ & $\mathrm{Ca} / \mathrm{K}$ & $\mathrm{Ca} / \mathrm{CTC}$ & $\mathrm{Mg} / \mathrm{CTC}$ & K/CTC \\
\hline ------- & $\mathrm{dm}^{3}$------ & $\%$ & $\%$ & - & - & - & \multicolumn{3}{|c|}{-------------- } \\
\hline 0.0 & 7.9 & 0.0 & 68 & 2.6 & 5.5 & 15.5 & 47.1 & 17.8 & 3.3 \\
\hline
\end{tabular}

Before transplanting, ten seedlings per parcel, were evaluated for health and quality, observing firmness, color and absence of pests on the leaves, root volume and size, uniform development and plant integrity, as recommended by Lima et al. (2012). After selection and visual standardization, the seedlings were immediately treated or not with the biostimulant and transplanted. The visual aspect of the seedlings at the time of transplanting can be seen in Figure 1.

Figure 1. Tomato hybrid H9553 seedlings with 20, 30, 40, 50, 60 e 70 days after sowing, respectively, from left to right.

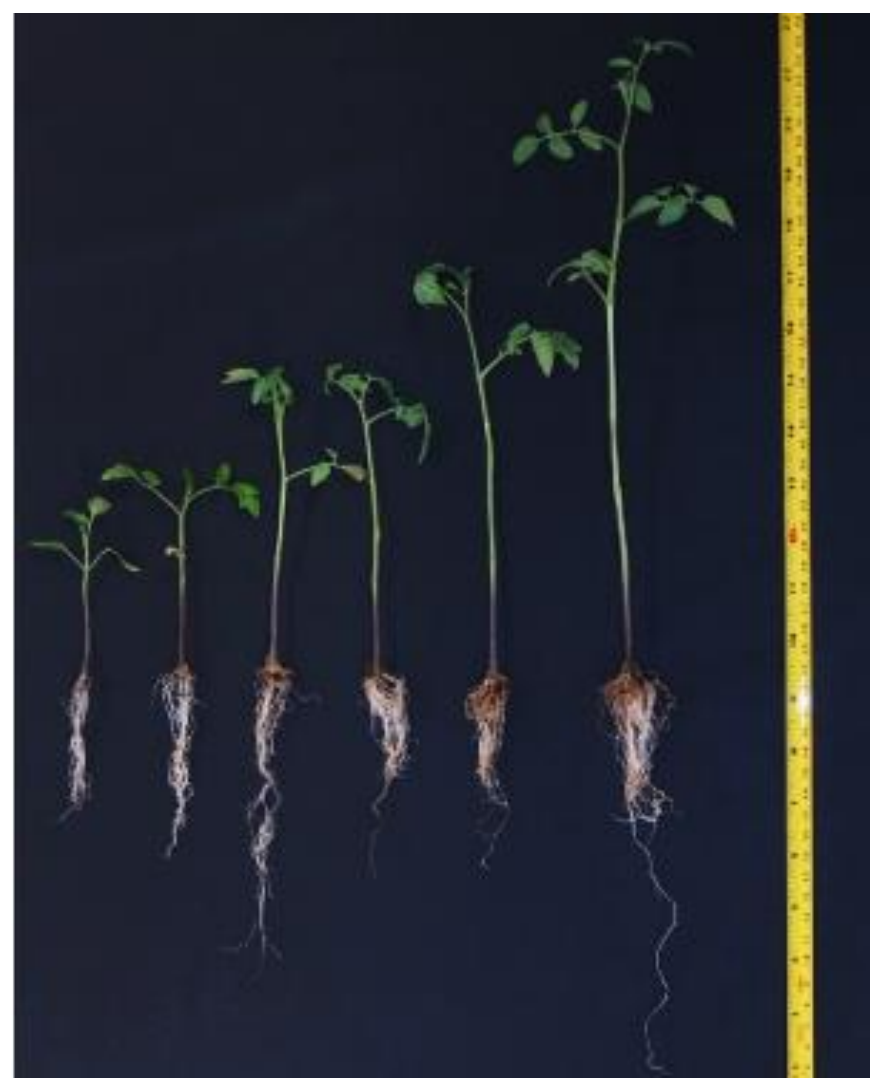


The biostimulant used was Stimulate ${ }^{\circledR}$, which contains in its formulation $0.009 \%$ kinetin (cytokinin), $0.005 \%$ gibberellic acid (gibberellin), 0.005\% indolbutyric acid (auxin) and 99.981\% inert ingredients (STOLLER DO BRASIL, 1998). Before transplanting, the product was applied to seedlings of all ages, at a concentration indicated by the package insert of $0.03 \mathrm{~mL} \mathrm{L-1}$, with the help of a backpack sprayer.

Fertigation was also performed, biweekly, after the $27^{\text {th }}$ DAT (days after transplanting) with urea, calcium nitrate and potassium chloride, corresponding to $40 \mathrm{~kg} \mathrm{~N} \mathrm{ha}^{-1}, 45 \mathrm{~kg} \mathrm{~N}$ and Ca ha ${ }^{-1}$ and $60 \mathrm{~kg} \mathrm{~K}_{2} \mathrm{O}$ ha $^{-1}$, respectively, with a Venturi injector.

In the field, the planting density used was 33,333 plants $\mathrm{ha}^{-1}$, with spacing between plants of $0.3 \mathrm{~m}$ and between rows of $1.0 \mathrm{~m}$. The irrigation was the located type via drip, with drippers spaced every $0.3 \mathrm{~m}$ with the capacity to apply $4 \mathrm{~L} \mathrm{H}_{2} \mathrm{O}$ per meter per hour, keeping the soil always close to the field capacity.

In order to avoid pests and diseases or nutritional deficiencies, weekly, sprays of insecticides and fungicides were performed, following the prescription instructions, with the aid of a backpack sprayer (Table 2). The foliar application of calcium and boron (Nutrioxi $\mathrm{CaB}$ $102^{\circ}$, Oxiquímica, at a dose of $2 \mathrm{~L} \mathrm{ha}^{-1}$ ) was also performed weekly to avoid the occurrence of plant apical rot.

Table 2. Products used throughout tomato hybrid H9553 cultivation as sanitary prophylaxis, their active ingredients and dosage.

\begin{tabular}{|c|c|c|}
\hline Comercial name $\left({ }^{\circledR}\right)$ & Active ingredient & Dosage \\
\hline Actara 250 WG & Thiamethoxam & 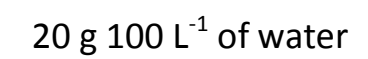 \\
\hline Belt SC & Flubendiamida & $60 \mathrm{~g} \mathrm{ha}^{-1}$ \\
\hline Bulldock 125 SC & Beta-Ciflutrina & $1.5{\mathrm{~g} 100 \mathrm{~L}^{-1} \text { of water }}$ \\
\hline Cabrio Top & Metiram+ Piraclostrobina & $120 \mathrm{~g} / 100 \mathrm{~L}^{-1}$ of water \\
\hline Certero & Triflumurom & $14.4 \mathrm{~g} / 100 \mathrm{~L}^{-1}$ of water \\
\hline Dithane NT & Mancozebe & $3 \mathrm{~kg} \mathrm{ha}^{-1}$ \\
\hline Evidence 700 WG & Imidacloprido & $210 \mathrm{~g} \mathrm{ha}^{-1}$ \\
\hline Galeão 700 WG & Imidacloprido & $200 \mathrm{~g} \mathrm{ha}^{-1}$ \\
\hline Recop & Oxicloreto de Cobre & $200 \mathrm{~g} 100 \mathrm{~L}^{-1}$ of water \\
\hline
\end{tabular}

The experimental design used was the randomized blocks with four replications, in a $2 \mathrm{x}$ 6 factorial scheme. The treatments consisted of seedlings without and with Stimulate ${ }^{\circ}$ and 6 seedlings ages $(20,30,40,50,60$ and 70 DAS days after sowing), totaling 12 treatments. The experiment consisted of 4 blocks (treatment repetition) with 12 plots each and 40 plants per plot, considering as a useful plot only the 16 central plants. Ten plants were used for evaluation in each plot.

Assessments were carried out in the seedling phase aged $20,30,40,50,60$ and 70 DAS and in the reproductive phase at 78 DAT. For evaluations were considered the stem diameter at the plant base, number of leaves, height, root length, fresh and dry mass of shoot and root. At 78 DAT, the length of the main stem, stem diameter at the plant base, number of fruits per plant, fruit mass per plant, average of fruit mass.

The data were submitted to analysis of variance by the $\mathrm{F}$ test at $1 \%$ and $5 \%$ of probability. When significant differences were found, regression analyses were performed.

\section{Results and Discussion}

The results of the variance analysis of the seedling evaluation regarding height, root length, stem diameter, number of leaves, fresh and dry mass of the shoot and roots are presented in 
Table 3, with the probability values for the effect of the factors evaluated, as well as the variation coefficients. For all variables there was a significant effect $(P<0.01)$ in relation to the seedlings age.

Table 3. Summary of variance analysis with $F$ values for height $(H)$, root length (RL), stem diameter (SD), leaves number (LN), shoot fresh mass (SFM), shoot dry mass (SDM), root fresh mass (RFM) and root dry mass (RDM) of the tomato hybrid H9553 seedlings at different ages.

\begin{tabular}{lcc}
\hline & $\mathbf{F}$ & $\mathbf{C V}(\%)$ \\
\hline $\mathrm{H}(\mathrm{cm})$ & $123.84^{* *}$ & 9.14 \\
$\mathrm{RL}(\mathrm{cm})$ & $42.82^{* *}$ & 15.05 \\
$\mathrm{SD}(\mathrm{mm})$ & $52.49^{* *}$ & 4.65 \\
LN (un.) & $82.02^{* *}$ & 7.59 \\
SFM (g) & $131.74^{* *}$ & 12.82 \\
SDM (g) & $221.66^{* *}$ & 12.32 \\
RFM (g) & $106.31^{* *}$ & 14.46 \\
RDM (g) & $142.39^{* *}$ & 12.10 \\
\hline
\end{tabular}

${ }^{* *}$ Significant by $\mathrm{F}$ test at $1 \% . \mathrm{CV}$ : variation coefficient.

The seedlings grew sharply until 70 DAS, with a difference of $373.4 \%$ in height when compared to the 20 DAS seedlings (Figure 2A). Root length, the 50 DAS seedlings had the highest values, with $18.42 \mathrm{~cm}$, which corresponds to an increase of $165.9 \%$ in relation to the 20 DAS seedlings, which had an average of $11.1 \mathrm{~cm}$. This fact can also be confirmed through the regression analysis, which presented a quadratic trend according to the seedlings age (Figures $2 \mathrm{~A}$ and 2B) for both variables.

For the stem diameter, an increasing behavior was observed as a function of the seedlings ages (Figure 2C). How much older they were, much larger were the diameters, with an increase of $160.4 \%$ in 70 DAS seedlings when compared to 20 DAS seedlings, evidenced through linear regression analysis (Figure $2 \mathrm{C}$ ). For the variable leaves number, there was also an increase as the seedlings got older, increasing from two leaves at 20 DAS to about five leaves at 70 DAS, occurring a quadratic trend growth according to the seedlings age (Figure 2D). 
Figure 2. Plant height (A), root length (B), stem diameter (C), leaves number (D) of tomato hybrid H9553 seedlings at different days after sowing (DAS). ${ }^{* *}$ Significant by $\mathrm{F}$ test at $1 \%$.
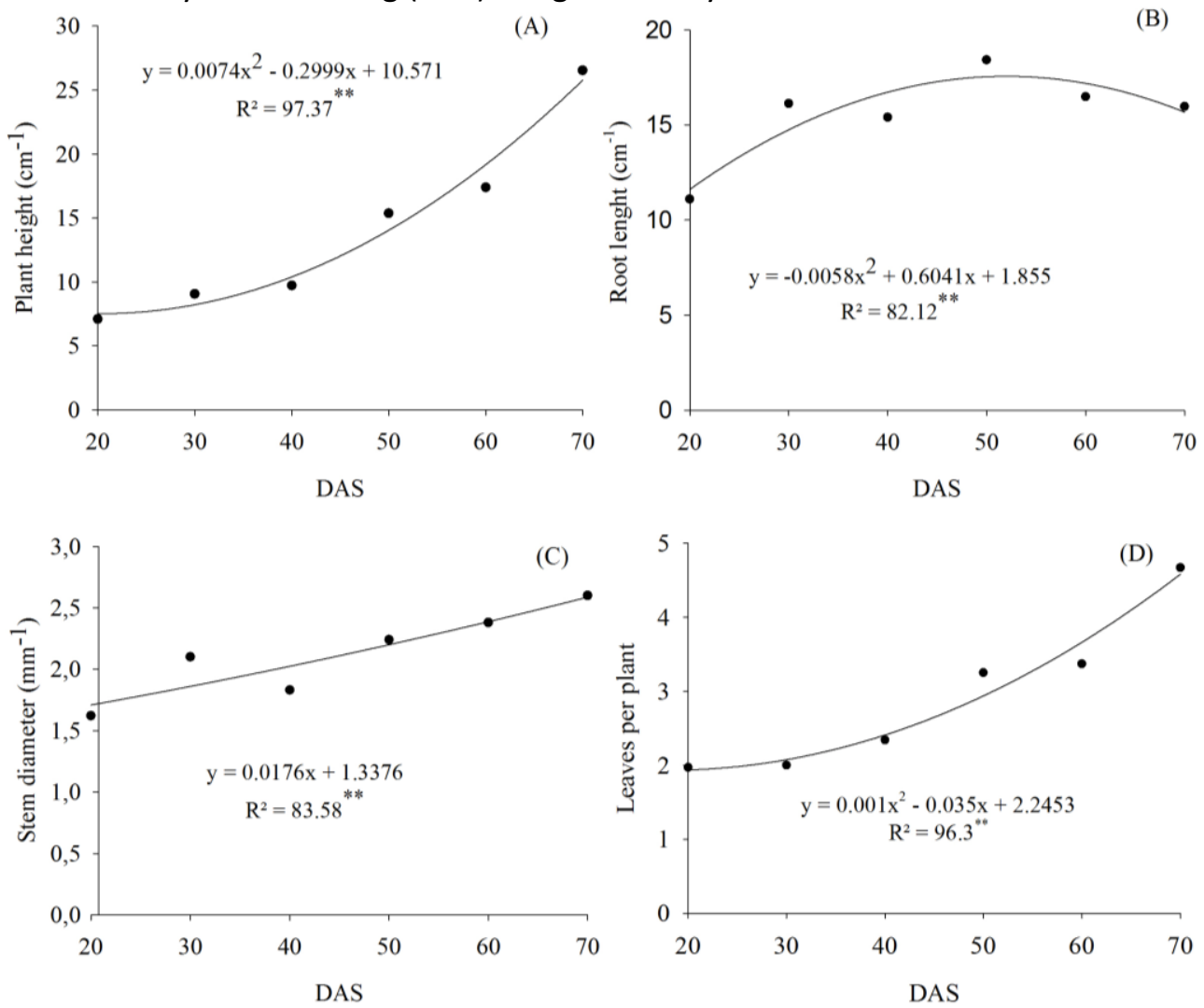

The increase in fresh mass of shoot and roots was proportional to the increase in seedlings age. At $70 \mathrm{DAS}, 2.37 \mathrm{~g}$ and $0.94 \mathrm{~g}$ were observed for shoot and root, respectively. For both variables, there was a quadratic trend growth according to the seedlings age (Figure $3 \mathrm{~A}$ and $3 \mathrm{~B})$. There was an increase in the dry mass of the shoot and roots of the seedlings proportional

to the age, following the same trend of the fresh mass. The dry mass increased from $0.02 \mathrm{~g}$ to twenty DAS to $0.29 \mathrm{~g}$ seventy DAS, for shoot, and from $0.01 \mathrm{~g}$ to twenty DAS to $0.09 \mathrm{~g}$ to seventy DAS, for root, showing a quadratic growth trend growth according to the seedlings age (Figure $3 \mathrm{C}$ and 3D). 
Figure 3. A. shoot fresh mass, B. root fresh mass, C. shoot dry mass, D. root dry mass of tomato hybrid H9553 seedlings at different days after sowing (DAS). ${ }^{* *}$ Significant by $\mathrm{F}$ test at $1 \%$.
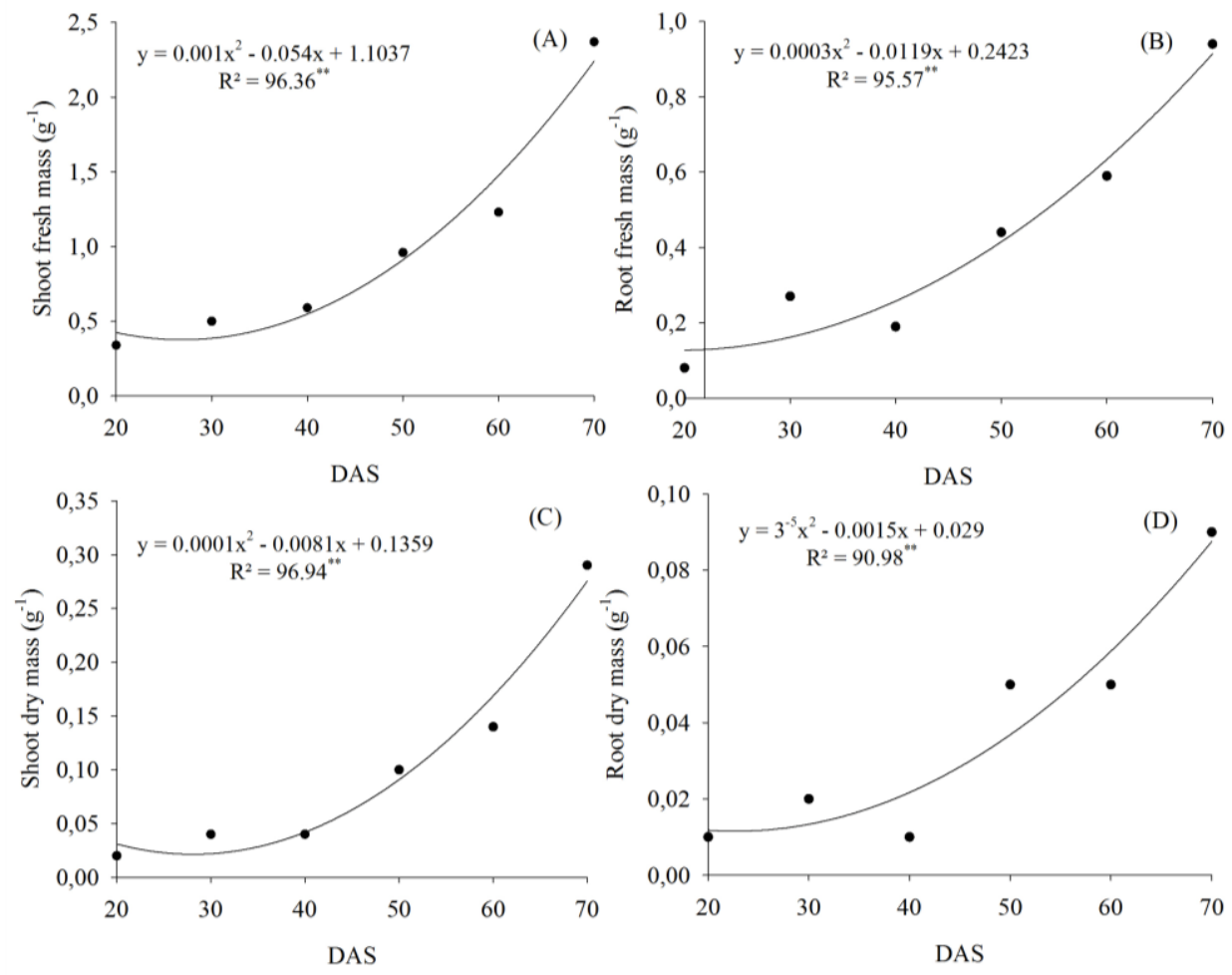

For length of the main stem, stem diameter, fruits number per plant, total fruit mass per plant and average of fruit mass at 78 DAT, there was no influence of the seedlings age not interaction between seedlings age and Stimulate application on the analyzed variables (Table 4). nor of the Stimulate application and there was

Table 4. Summary of variance analysis with $F$ values for the length of the main stem (CMS), stem diameter (SD), fruits number per plant (FN), total fruits mass per plant (TFM) and average fruits mass (AFM) of tomato hybrid $\mathrm{H} 9553$ plants at 78 days after transplantation (DAT).

\begin{tabular}{lccccc}
\hline \multirow{2}{*}{ Variable } & CMS & SD & FN & TFM & AFM \\
\cline { 2 - 6 } & $\mathbf{( c m )}$ & $\mathbf{( m m )}$ & (un.) & $\mathbf{( g )}$ & $\mathbf{( g )}$ \\
\hline Stimulate $^{\circ}(\mathrm{S})$ & $1.13 \mathrm{~ns}$ & $1.47 \mathrm{~ns}$ & $0.08 \mathrm{~ns}$ & $2.38 \mathrm{~ns}$ & $1.70 \mathrm{~ns}$ \\
Age (A) & $1.47 \mathrm{~ns}$ & $1.43 \mathrm{~ns}$ & $5.81 \mathrm{~ns}$ & $0.08 \mathrm{~ns}$ & $0.34 \mathrm{~ns}$ \\
Sx A & $1.74 \mathrm{~ns}$ & $0.30 \mathrm{~ns}$ & $0.82 \mathrm{~ns}$ & $1.96 \mathrm{~ns}$ & $1.29 \mathrm{~ns}$ \\
\hline CV (\%) & 14.22 & 9.44 & 18.80 & 20.54 & 16.98 \\
Average & 66.25 & 11.29 & 37.38 & 782.35 & 21.41 \\
\hline
\end{tabular}

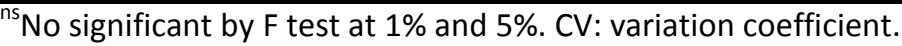

The best age of tomato seedlings transplantation has been investigated in several studies because its importance to the proper adult plant formation (GOTO et al., 2010; JAISWAL et al., 2017). However, there is no consensus, since there are several factors to be taken into account, ranging from the impact of the seedling age on the plant's phytosanitary conditions, because it influences the degree of damage and exposure of its tissues during transplantation, what can facilitate infection by pathogenic microorganisms (THOMAS; UPRETI, 2014), to a root system that provides better tolerance to water availability of the cultivation environment (RODRIGUES et al., 2010). It is also considered better root-clod integrity (GUEDES et al., 2015; ALAGUERO-CORDOVILLA et al., 2018), a stem structure less sensitive to mechanical 
impacts and strong enough not to succumb to the winds (BOVI; MINAMI, 1999), number of leaves or leaf area that provides less damage to the photosynthetic apparatus during transplanting (MCCALL, 1992) or a general structure less sensitive to transplantation management (SARKER et al., 2017; VIVEK; DURAISAMY, 2017).

For nurseries and farmers there is interest in reducing the seedling cost production and the cost and time between transplanting and production (GOTO et al., 2010; JAISWAL et al., 2017). Among the most diverse factors to be considered, one is essential in any analysis, which is whether the age of the seedling when transplanted interferes on fruit production (JANKAUSKIENO et al., 2013; JAISWAL et al., 2017). For this factor, the response is variable according to the environment and the genotype (SARKER et al., 2017). Although, for some tomato genotypes, the age of the transplanted seedling interferes on fruit production (GOTO et al., 2010; JAISWAL et al., 2017), for others there is no interference as we observed in this present work, corroborating the research of Leskovar et al. (1991).

The seedlings had normal growth along the experiment. It is evidenced by the linear or quadratic model for the evaluated growth parameters. It was already expected, since no problem was faced and there was no interruption of any of the cultural treatments necessary for plant growth. At the same time, there was linear increase of the leaves number, and consequently, in the photosynthetic area responsible for the production of photoassimilates to be allocated in all organs.

Since we observed that the tomato hybrid H9553 genotype seedlings age, at transplanting, does not interfere on fruit production, under the conditions of this experiment, it is worth mentioning that less time in seedling production could benefit the producer by increasing the nursery turnover, as well as decrease the cost of production. However, it is important to be alert to the various aspects above mentioned about the decision when to transplant, considering various different environments and growing conditions.

As well as the age of the seedlings, the use of the Stimulate biostimulant, when applied before transplanting, does not interfere on plants development in the field or in fruit production.

The Stimulate use in the tomato seedlings development (SIRTOLI et al., 2008;
VENDRUSCOLO et al., 2016a, 2016b), as well as other vegetables (IZIDÓRIO et al., 2015; VENDRUSCOLO et al., 2016a), beyond researches, has also been used by some producers searching better seedlings quality. Although most of these researches has observed positive results on seedlings development, those that link its use to final crop yield are still incipient, although it is known that it is a practice that raises the production cost. Positive results on crop yield have already been reported for grafted peppers of the Golden and Zarco hybrids (PALANGANA et al., 2012), but no effect was observed for the All Big cultivar (ZEIST et al., 2018). In rocket its use promoted an increase in production of the Rokita cultivar, but not in the Folha Larga cultivar (SILVA et al., 2018). In tomato it promoted increase in commercial fruit quality in the Carmen cultivar (TAVARES et al., 2015), as well as increase in the fruit dry mass of the Micro-Tom cultivar (CATO et al., 2013), however, as we observed in this present study for the H9553 hybrid, for the tomato hybrid Paronset and Myla the Stimulate use also did not alter the fruit production (WEBER, 2015). Based on these studies, it is possible to infer that the effectiveness of this biostimulant use on production depends on the genotype, and, therefore, its use for crop yield purposes does not always culminate into productive return.

Stimulate ${ }^{\circ}$ use promoted desirable growth increase in vegetative organs of many species (MASONDO et al., 2019; MONTEIRO et al., 2019; NEMAHUNGUNI et al., 2020). However, there was no effect of this biostimulant on production and dry mass of sweet potato tubers (RÓS et al., 2015) nor in the growth of rocket roots (HAJAR et al., 2015), as well as did not interfere in the dry mass of shoot and roots of coffee seedlings (MELO; MACIEL, 2014). The use even triggered a decrease of the watermelon roots growth (SILVA et al., 2014) and also in leaves and total dry mass in lettuce (IZIDÓRIO et al., 2015). Growth reduction was also observed in passion fruit seedlings (GONÇALVES et al., 2018). For tomato, Gaúcho and Santa Clara cultivars, the Stimulate use promoted vegetative growth aspects (VENDRUSCOLO et al., 2016a, 2016b), but it has also not been a common response of the species, since Sirtoli et al. (2008) did not observe effect on shoot dry mass in grafted Pizzadoro and Spirit hybrids, just as there was no effect on the vegetative growth of the H9553 hybrid, observed in this present work. 
The non-interference of Stimulate ${ }^{\bullet}$ on vegetative growth aspects, like seen in this work, leads us to infer that its effectiveness is conditioned to different physiological states of the plants, because it is a biostimulant composed of three hormonal substances. Therefore, it is known that hormones have a pleiotropic effect, regulating, at the same time, many aspects of plant development, and also have a character of interaction among themselves, interacting synergistically or antagonically, regulating and modulating development aspects (DAVIES, 2013; MUNNÉ-BOSCH; MÜLLER, 2013). Exactly because of these characteristics, the results obtained from Stimulate application can vary very much because it can interfere, at same time, in wide aspects of plant metabolism and development, and this can bring even unexpected results. As the results can be unpredictable, scientific research is needed for the different purposes and different genotypes to be studied. In this case, if the desired result is not achieved, there will be an additional and unnecessary production cost. Considering that the hormonal action is variable according to plant genotype and environment, the results of its application also depends on the concentration and frequency applied and also the receiving organ and its respective age.

\section{Conclusions}

Seedlings with seventy days show superior results for height, number of leaves, diameter and dry mass of leaves and roots, however, this does not interfere in the crop yield.

The use of the Stimulate ${ }^{\circledR}$ biostimulant, alone or in interaction with the age of the seedlings, does not influence the growth or the characteristics related to productivity, for the hybrid tomato $\mathrm{H} 9553$.

\section{References}

AGEHARA, S.; LESKOVAR, D. I. Growth suppression by exogenous abscisic acid and uniconazole for prolonged marketability of bell pepper transplants in commercial conditions. Scientia Horticulturae, v.194, p.118-125, 2015. https://doi.org/10.1016/i.scienta.2015.08.010

ALAGUERO-CORDOVILLA, A.; GRAN-GÓMEZ, F. J.; TORMOS-MOLTÓ, S.; PÉREZ-PÉREZ, J. M. Morphological characterization of root system architecture in diverse tomato genotypes during early growth. International journal of molecular sciences, v.19, n.12, e-3888, 2018. https://doi.org/10.3390/ijms19123888

BOVI, J. E.; MINAMI, K. Condicionamentos mecânicos de mudas de tomateiro (Lycopersicon esculentum Mill.). Scientia Agrícola, v.56, n.1, p.97-101, 1999. https://doi.org/10.1590/S0103$\underline{90161999000100015}$

CATO, S. C.; MACEDO, W. R.; PERES, L. E. P. Sinergism among auxins, gibberellins and cytokinins in tomato cv. Micro-Tom. Horticultura Brasileira, v.31, n.4, p.549-553, 2013. https://doi.org/10.1590/S0102$\underline{05362013000400007}$

COMISSÃO DE FERTILIDADE DE SOLOS DE GOIÁS. Recomendações de corretivos e fertilizantes para Goiás 5a Aproximação. Goiânia, UFG/EMGOPA, 1988. 101p.

COSTA, J. M.; HEUVELINK, E. The global tomato industry. In: HEUVELINK, E. (ed.). Tomatoes. 2. ed. CABI, 2018. p.1-26. (Crop Production Science in Horticulture Series; v.27). https://doi.org/10.1079/9781780641935.0001

DAVIES, P. J. (Ed.). Plant hormones: physiology, biochemistry and molecular biology. Springer Science \& Business Media, 2013.

GONÇALVES, B. H. L.; SOUZA, J. M. A.; FERRAZ, R. A.; TECCHIO, M. A.; LEONEL, S. Efeito do bioestimulante Stimulate ${ }^{\circledR}$ no desenvolvimento de mudas de maracujazeiro cv. BRS Rubi do Cerrado. Revista de Ciências Agrárias, v.41, n.1, p.151-160, 2018. http://dx.doi.org/10.19084/RCA16077

GOTO, R.; SIRTORI, L. F.; RODRIGUES, J. D.; LOPES, M. C. Produção de tomateiro, híbrido momotaro, em função do estádio das mudas e da enxertia. Ciência e Agrotecnologia, v.34, n.4, p.961-966, $2010 . \quad$ https://doi.org/10.1590/S1413$\underline{70542010000400023}$

GUEDES, R. A.; OLIVEIRA, F. D. A. D.; ALVES, R. D. C.; MEDEIROS, A. S. D.; GOMES, L. P.; COSTA, L. P. Estratégias de irrigação com água salina no tomateiro cereja em ambiente protegido. Revista Brasileira de Engenharia Agrícola e Ambiental, v.19, n.10, p.913-919, 2015. https://doi.org/10.1590/18071929/agriambi.v19n10p913-919 
HAJAR, A.; SENA, E. S. G.; DINIZ, K. P.; SILVA, J. R.; SILVA, V. N. Biorregulador: influência na produção de mudas de rúcula. Anais do Salão Internacional de Ensino, Pesquisa e Extensão, v.7, n.2, p.01-01, 2015.

IZIDÓRIO, T. H. C.; LIMA, S. F.; VENDRUSCOLO, E. P.; ÁVILA, J.; ALVAREZ, R. C. F. Bioestimulante via foliar em alface após o transplantio das mudas. Revista de Agricultura Neotropical, v.2, n.2, p.4956, 2015. https://doi.org/10.32404/rean.v2i2.257

JAISWAL, A. K.; SINGH, J. P.; TOMAR, S. Effect of Seedlings Age on Growth, Yield Attributes and Yield of Tomato (Lycopersicon esculentum Mill.). International Journal of Current Microbiology and Applied Sciences, v.6, n.9, p.1521-1524, 2017.

https://doi.org/10.20546/ijcmas.2017.609.185

JANKAUSKIENƠ, J.; BRAZAITYTO', A.; BOBINAS, Ý.; DUCHOVSKIS, P. Effect of transplant growth stage on tomato productivity. Hortorum Cultus, v.12, n.2, p.143-152, 2013.

JORGE, M. H. A.; ANDRADE, R. J.; COSTA, E. O mercado de mudas de hortaliças. In: NASCIMENTO, W. M.; PEREIRA, R. B. (Eds.). Produção de mudas de hortaliças. Brasília: Embrapa, 2016. p.15-32.

LESKOVAR, D. I.; CANTLIFFE, D. J.; STOFFELLA, P. J. Growth and yield of tomato plants in response to age of transplants. Journal of the American Society for Horticultural Science Jashs, v.116, n.3, p.416-420, 1991. https://doi.org/10.21273/JASHS.116.3.416

LIMA, G. G. S.; NASCIMENTO, A. R.; ÁZARA, N. A. Produção de mudas. In: CLEMENTE, F. M. V. T.; BOITEUX, L. S. Produção de tomate para processamento industrial. Brasília: Embrapa, 2012. p.79-101.

MAGRO, F. O.; SALATA, A. C.; BERTOLINI, E. V.; CARDOSO, A. I. I. Produção de repolho em função da idade das mudas. Revista Agroambiente Online, v.5, n.2, p.119-123, 2011. https://doi.org/10.18227/1982-

8470ragro.v5i2.416

MASONDO, N. A.; KULKARNI, M. G.; FINNIE, J. F.; VAN STADEN, J. Influence of biostimulants-seed- priming on Ceratotheca triloba germination and seedling growth under low temperatures, low osmotic potential and salinity stress. Ecotoxicology and Environmental Safety, v.147, p.43-48, 2019.

https://doi.org/10.1016/j.ecoenv.2017.08.017

McCALL, D. Effect of supplementary light on tomato transplant growth, and the after-effects on yield. Scientia horticulturae, v.51, n. 1-2, p.6570, 1992. https://doi.org/10.1016/03044238(92)90104-K

MELO, B. M. R.; MACIEL, A. L. R. Influência de bioativadores e bioestimulantes na produção de mudas de cafeeiros. Revista Agrogeoambiental, v.6, n.3, p.55-61, 2014. http://dx.doi.org/10.18406/2316$\underline{1817 v 6 n 32014589}$

MONTEIRO, G. C.; SILVA, M. B.; RODRIGUES, L. F. O. S.; BALDINI, L. F.; SILVA, E. G.; TAKATA, W. H. S.; GOTO, R. Aplicação de bioestimulante proporciona melhoria no cultivo da beterraba (Beta vulgaris L.). Revista de Ciências Agrárias, v.42, n.4, p.1024-1031, 2019. https://doi.org/10.19084/rca.17477

MUNNÉ-BOSCH, S.; MÜLLER, M. Hormonal crosstalk in plant development and stress responses. Frontiers in plant science, v.4, p.529, 2013. https://doi.org/10.3389/fpls.2013.00529

NEMAHUNGUNI, K. N.; GUPTA, S.; KULKARNI, M. K.; FINNIE, J. F.; STADEN, J. V. The effect of biostimulants and light wavelengths on the physiology of Cleome gynandra seeds. lant Growth Regulation, v.90, p.467-474, 2020. https://doi.org/10.1007/s10725-019-00546-7

PALANGANA, F. C.; SILVA, E. S.; GOTO, R.; ONO, E. $O$. Ação conjunta de citocinina, giberelina e auxina em pimentão enxertado e não enxertado sob cultivo protegido. Horticultura Brasileira, v.30, n.4, p.751-755, 2012. https://doi.org/10.1590/S0102$\underline{05362012000400031}$

RODRIGUES, E. T.; LEAL, P. A.; COSTA, E.; PAULA, T. S.; GOMES, V. D. A. Produção de mudas de tomateiro em diferentes substratos e recipientes em ambiente protegido. Horticultura Brasileira, v. $28, \quad$ n. $4, \quad$ p.483-488, 2010. 
https://doi.org/10.1590/S0102-

\section{$\underline{05362010000400018}$}

RÓS, A. B.; NARITA, N.; ARAÚJO, H. S. Efeito de bioestimulante no crescimento inicial e na produtividade de plantas de batata-doce. Revista Ceres, v.62, n.5, p.469-474, 2015. https://doi.org/10.1590/0034737X201562050007

SARKER, R.; RAY, S. P.; PAUL, J.; NUSRAT, A.; MALLICK, S. R. Interaction effect of seedling age and different doses of $\mathrm{GA}_{3}$ on growth and yield of tomato (Lycopersicon esculentum Mill.). Archives of Agriculture and Environmental Science, v.2, n.4, p.301-304, 2017. https://doi.org/10.26832/24566632.2017.020409

SEABRA JÚNIOR, S.; GADUN, J.; CARDOSO, A. I. I. Produção de pepino em função da idade das mudas produzidas em recipientes com diferentes volumes de substrato. Horticultura Brasileira, v.22, n.3, p.610-613, 2004. https://doi.org/10.1590/S0102$\underline{05362004000300022}$

SILVA, J; GUEDES, I. M. R.; LIMA, C. E. P. Adubação e nutrição. In: CLEMENTE, F. M. V. T.; BOITEUX, L. S. Produção de tomate para processamento industrial. Brasília, Embrapa, 2012. p. 105-130.

SILVA, M. J. R. D.; BOLFARINI, A. C. B.; RODRIGUES, L. F. O. S.; ONO, E. O.; RODRIGUES, J. D. Formação de mudas de melancia em função de diferentes concentrações e formas de aplicação de mistura de reguladores vegetais. Scientia Plena, v.10, n.10, e-109906, 2014.

SILVA, V. N.; HAJAR, A. S.; DOTTO, L.; SENNA, E. G.; MENEZES, H. M.; DINIZ, K. P. Efeito de biorregulador na germinação e crescimento de plântulas de rúcula (Eruca sativa L.). Revista Biociências, v.23, n.1, p.69-75, 2018.

SIRTOLI, L. F.; CERQUEIRA, R. C.; FERNANDES, L. M. S.; RODRIGUES, J. D.; GOTO, R.; MEDEIROS, M. $O$. Resposta a aplicação de diferentes reguladores vegetais em mudas enxertadas de tomateiro. Biodiversidade, v.7, n.1, p.29-36, 2008.

STOLLER DO BRASIL. Stimulate Mo em hortaliças: informativo técnico. Cosmópolis-SP: Stoller do Brasil, 1998.
TAVARES, S.; CASTRO, P.; AMBROSANO, E.; CATO, S.; FOLTRAN, D. Efeitos de Bioestimulante no Desenvolvimento de Frutos de Tomateiro 'Carmen'. Cadernos de Agroecologia, v.9, n.4, p.1-10, 2015.

THOMAS, P.; UPRETI, R. Influence of seedling age on the susceptibility of tomato plants to Ralstonia solanacearum during protray screening and at transplanting. American Journal of Plant Sciences, v.5, n.12, p.1755-1762, 2014. https://doi.org/10.4236/ajps.2014.512190

VENDRUSCOLO, E. P.; MARTINS, A. P. B.; SELEGUINI, A. Promoção no desenvolvimento de mudas olerícolas com uso de bioestimulante. Journal of Agronomic Sciences, v.5, n.2, p.73-82, 2016 a.

VENDRUSCULO, E. P.; CAMPOS, L. F. C.; MARTINS, A. P. B.; SELEGUINI, A. $\mathrm{GA}_{3}$ em sementes de tomateiro: efeitos na germinação $e$ desenvolvimento inicial de mudas. Revista de Agricultura Neotropical, v.3, n.4, p.19-23, 2016b. https://doi.org/10.32404/rean.v3i4.1165

VIVEK, P.; DURAISAMY, V. Study of growth parameters and germination on tomato seedlings with different growth media. International Journal of Agricultural Science and Research, v.7, n.3, p.461-470, 2017. https://doi.org/10.24247/ijasriun201759

WEBER, R. E. H. Aplicação de reguladores vegetais na produção e qualidade de frutos do tomateiro. 2015. Dissertação (mestrado) Universidade Estadual Paulista Júlio de Mesquita Filho, Faculdade de Ciências Agronômicas de Botucatu, 2015.

ZEIST, A. R.; ZANIN, D. S.; CAMARGO, C. K.; RESENDE, J. T.; ONO, E. O.; RODRIGUES, J. D. Produção e trocas gasosas do pimentão em função da aplicação foliar de boro, cálcio e Stimulate. Horticultura Brasileira, v.36, n.4, p.498-503, 2018. https://doi.org/10.1590/s0102$\underline{053620180412}$ 